\title{
Indirect effect of environmental factors on interactions between microbial and classical food webs in freshwater ecosystems
}

\author{
Małgorzata Adamczuk*, Tomasz Mieczan, Dorota Nawrot and Jacek Rechulicz \\ Department of Hydrobiology, University of Life Sciences, B. Dobrzańskiego 37, Lublin 20-262, Poland
}

Received 8 May 2014; Accepted 31 October 2014

\begin{abstract}
The role of environmental factors in aquatic ecosystems results from basic lake characteristics, human disturbances ('cultural eutrophication') and climate-related trends in the physical and chemical components of lakes. Although the influence of environmental factors on the abundance of aquatic animals is fairly well documented, less has been done to research their influence on food web interactions. The aim of the study was to evaluate microbial and classical food webs in lakes, with special emphasis placed on the role of environmental factors as influencing strengths. Variation partitioning, based on redundancy analysis, revealed that environmental factors played the most important role in structuring aquatic communities by accounting for $87.5 \%$ of their variation. Among all the factors measured, total solids (TS), transparency (Secchi disc) and temperature were most closely related to the variation in trophic communities. The analyses of food web interactions under low and high levels of those factors revealed that they differently influenced strengths among food web components. The strongest relations among distinct trophic levels were found under conditions of low TS, the lowest number of relations was found under conditions of low temperature. Only in low TS did bacteria correlate significantly with biogenes. Under high TS, bacteria positively influenced plenty of higher trophic levels. Top-down control was observed under conditions of high temperature. Conditions of low and high transparency did not diversify food web interactions. The obtained results can broaden our knowledge of the response of food webs to environmental factors in advanced stages of global eutrophication of water bodies and in the early stage of projected trends of global climate change.
\end{abstract}

Key words: Total solids / transparency / temperature / eutrophication / climate change

\section{Introduction}

The food web constitutes one of the most complex conceptual phenomena in modern biology (Pimm et al., 1991). Food webs in aquatic ecosystems function via challenging the energy and flux of materials among diverse organism assemblages organized into two chains: the so-called 'microbial loop' and the classical grazing chain. They are regulated both by top-predator (top-down control) and nutrient resources (bottom-up control), and the strength of this control is dependent on trophic position and food web length (Brett and Goldman, 1997). Up until now, a countless number of possible relations between distinct levels of microbial and classical food webs in freshwater and marine ecosystems has been described (e.g., Beaver and Crisman, 1982; Güde, 1986; Jack and Gilbert, 1993; Wickham, 1995a, 1995b; Jürgens and Jeppesen, 2000). Although it is well established that fish can impact lower

\footnotetext{
*Corresponding author: malgorzata.adamczuk@up.lublin.pl
}

trophic levels through cascading trophic interactions (Carpenter et al., 1985; Brett and Goldman, 1996), and that the microbial loop plays an important role in carbon cycling and nutrient remineralization, the relative strengths of interactions between the classical aquatic food web and the microbial food web are poorly understood. A poor understanding of these strengths results from the fact that natural aquatic ecosystems do not exist in a state of equilibrium but function under continuous changes induced by independent environmental factors. These environmental factors basically result from a lake's characteristics (Dawidek et al., 2013), but they are also created by human disturbances (so-called 'cultural eutrophication'; Smil, 2000) and climate-related trends in the physical and chemical components of lakes (Straile et al., 2003; Winder and Schindler, 2004). The influence of environmental factors is fairly well documented as cases of seasonal and spatial differences in aquatic animals' abundance and biomass. However, studies on their relations to food web interactions are scarce. The aim of the study was to evaluate microbial and classical food webs in 


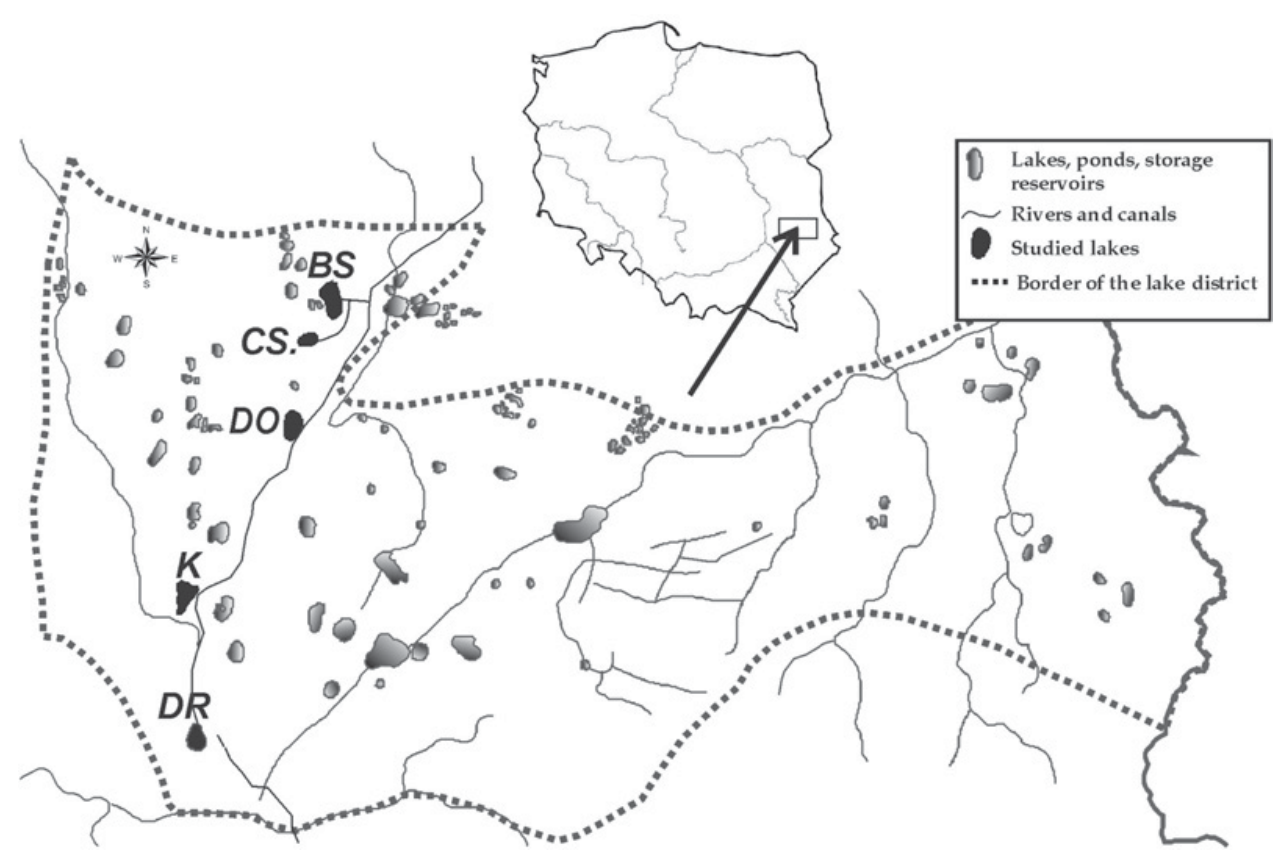

Fig. 1. Location of the study area. The studied lakes are marked with symbols: BS - Lake Białe Sosnowickie, CS - Lake Czarne Sosnowickie, DO - Lake Domaszne, K - Lake Krzczeń, DR - Lake Dratów.

lakes with special emphasis on the role of environmental factors as influencing their strengths. The general hypothesis was that interactions among distinct trophic levels of microbial and classical food webs are influenced by environmental factors. Thus, components of food webs and the values of environmental factors were identified in the study. Thereafter, ordination analysis was used to evaluate which of the environmental factors significantly influenced the food web components. In a further analysis, interactions between trophic levels were analysed under the evaluated environmental factors. Understanding and potentially forecasting the impact of environmental factors on food web interactions may help us to predict changes in aquatic ecosystems in the current era of cultural eutrophication and putative trends of climate change.

\section{Materials and methods}

The lakes selected to conduct the study are five eutrophic reservoirs situated in the area of the LęcznaWłodawa Lake District (Eastern Poland), i.e., Lake Dratów, Lake Krzczeń, Lake Domaszne, Lake Czarne Sosnowickie and Lake Białe Sosnowickie (Figure 1). The lakes are located between $51^{\circ} 33^{\prime} 92^{\prime \prime}-51^{\circ} 53^{\prime \prime} 11^{\prime \prime} \mathrm{N}$ and $22^{\circ} 94^{\prime} 64^{\prime \prime}-23^{\circ} 04^{\prime} 75^{\prime \prime} \mathrm{W}$. They are shallow and small, as the mean depth does not exceed $5 \mathrm{~m}$, the area reaches $1.5 \mathrm{~km}^{2}$ at maximum, and the volume of the largest lake is $2020 \mathrm{~m}^{3}$. In 1961, they were transformed into storage reservoirs and connected together by a man-made canal supplying high biogene-fecund waters (Dawidek et al., 2004). The lakes are systematically stocked with fry.
Microbial communities (bacteria, heterotrophic nanoflagellates (HNF and ciliates), crustaceans (cladocerans and copepods) and fish were examined in the open water zone of each lake. The samples were taken monthly from April 2012 to October 2013. At each of the sites, planktonic communities were collected from the middle of the water column using a $5 \mathrm{~L}$ Bernatowicz sampler. The bacterial biomass was determined by means of DAPI (4'6-diamidino-2-phenylindole)-staining and epifluorescence microscopy according to the method of Porter and Feig (1980). A total of $10 \mathrm{ml}$ of water was preserved with formaldehyde to a final concentration of $2 \%$ and kept in the dark at $4{ }^{\circ} \mathrm{C}$. Four slides were made from each sample in which subsamples of $2 \mathrm{ml}$ were filtered on $0.2 \mu \mathrm{m}$ poresize polycarbonate filters that were stained with irgalan black. The bacteria were counted in 250 randomly chosen fields of view. Biovolumes of the microbial community were estimated assuming geometric shapes and converting to carbon using the following conversion factor (Gilbert et al., 1998). Each sample of HNF was fixed in situ with formalin (a final concentration of $2 \%$ ). Subsamples of $10 \mathrm{ml}$ for HNF were stained with DAPI (final concentration $1 \mu \mathrm{g} \cdot \mathrm{mL}^{-1}$ ) (Porter and Feig, 1980), filtered through black polycarbonate membrane filters (Millipore) with a pore size of $0.8 \mu \mathrm{m}$ for HNF, and enumerated by means of epifluorescence microscopy. The HNF biovolume was calculated from measurements of cells and approximated to simple geometrical forms (Kalinowska, 2004). The community composition of ciliates was determined using Utermöhl's method. Five-litre samples were filtered through a plankton net of $10 \mu \mathrm{m}$ mesh size. Samples (whole sample $=500 \mathrm{ml}$ ) were sedimented for $24 \mathrm{~h}$ in a cylinder stoppered with. In order to determine the density, 
three samples were preserved with Logol's solution and stored in the dark at a temperature of $4{ }^{\circ} \mathrm{C}$. Observation of live samples was used for taxonomic and trophic identification. Ciliates are highly perishable and their type of motility is a species-specific feature; for this reason, species determination and measurements were carried out on live material immediately after returning to the laboratory and after silver impregnation (Augustin et al., 1984). Ciliate biomass was estimated by multiplying the numerical abundance by the mean cell volume $\left(1 \mu \mathrm{m}^{3}=1 \mathrm{pg}\right)$ calculated from direct volume measurements using appropriate geometric formulas (Finlay, 1982). Obvious shrinkage of stained ciliates was noticeable after silver preparation. Therefore, the calculated cell volumes were multiplied with a correcting factor of 0.4 (Jerome et al., 1993). In the case of Crustacea (Cladocera and Copepoda), double samples of the volume $0.5 \mathrm{dm}^{3}$ were collected and pooled to reduce heterogeneity in crustacean distribution and sampling variability, thus the final volume of a sample measured $1 \mathrm{dm}^{3}$. Each sample was taken in three replications. Samples were sieved through in a $40 \mu \mathrm{m}$ mesh net and fixed with formalinglycerine solution. In the laboratory, the classification and counts of crustaceans were made with the use of the Sedgewick-Rafter cell. Crustacean biomass was estimated on relations between the body length and body mass of a given specimen (Dumont et al., 1975; Bottrell et al., 1976; Culver et al., 1985) by applying established mathematical formulas.

Fish were caught using the standard Norden $\mathrm{S}$ multimesh gillnet type $(10,60,30,6.25,43,22,50,33,12.5,25$, 8, 38, 75, $16.5 \mathrm{~mm}$ ) (Appelberg, 2000, CEN document, 2005). At each fish sampling, two nets were placed in open water in the evening for $12 \mathrm{~h}$. The gillnets were placed in mid-water so as to cover the height of the water column as much as possible. Caught fish were determined to the species level and trophic group (planktivorous and predatory fish), and their body mass (in g) was measured. Fish data were converted to weight per unit effort (WPUE) as fish biomass (in grams) caught in one net after $12 \mathrm{~h}$ of fishing.

Simultaneously to the biological studies, a number of physical and chemical analyses were conducted. Transparency was estimated with the use of a Secchi disc (SD). Temperature, conductivity, $\mathrm{pH}$ and dissolved oxygen (DO) were determined in situ with a multiparametric probe. Total organic carbon (TOC), total suspended solids (TSS), surface active agents (SUR), chemical oxygen demand (COD) and biological oxygen demand (BOD) were determined using the PASTEL UV spectrophotometer, and the remaining factors (TS - total solids, TP - total phosphorus, $\mathrm{P}-\mathrm{PO}_{4}, \mathrm{~N}-\mathrm{NH}_{4}, \mathrm{~N}-\mathrm{NO}_{3}$ chlorophyll-a) were analysed in the laboratory (Golterman, 1969).

The differences in physical and chemical water parameters were analysed by means of one-way analysis of variance (ANOVA). Spearman's rank correlation coefficients $(r)$ were calculated for pairs of environmental variables to recognize which of the variables were intercorrelated. Redundancy analysis (RDA) was used to explore relationships between the abundance of taxonomic groups and environmental factors (Lepš and Šmilauer, 2003). The choice of this linear ordination model was justified by the narrow range of the data (previously assessed by DCA with a length of gradient $<2$ standard deviations). On the resultant plot, arrows representing the factors indicate the direction of their maximum change, and the length of each arrow is proportional to the rate of change. The proportion of variance explained by each factor was quantified using variance partitioning. RDA analysis was performed using a selection in which the Monte Carlo test of significance for all factors was assessed, and only then statistically significant factors were taken into account for further analysis. The data were logtransformed $\ln (x+1)$ prior to the analysis (Ter Braak and Šmilauer, 2002). Ordination analyses were performed by means of CANOCO 4.5 for Windows. The next step was to check which threshold values (TV) of each factor graded the densities of distinct communities. Therefore, we tested the differences in biomass in relation to factors using one-factorial ANOVA to find the lowest value of a given factor that significantly diversified the communities' biomasses. TV were used to estimate low $(\leq \mathrm{TV})$ and high ( $>$ TV) values of the considered factors. Pearson's correlation coefficients were used to find interactions between distinct trophic levels under low and high values of the factors. Correlations were performed on the communities' biomasses and the data were log-transformed prior to analysis.

\section{Results}

\section{Components of the microbial food web (bacteria, flagellata and ciliata)}

The biomass of bacteria ranged between $0.91 \pm$ $0.89 \mathrm{mg} . \mathrm{dm}^{-3}$ in Lake Dratów and $1.85 \pm 1.40 \mathrm{mg} \cdot \mathrm{dm}^{-3}$ in Lake Krzczen, and did not differ among the studied lakes $(F=0.65$, d.f. $=5, P=0.66)$. Lake Krzczeń showed the lowest biomass of flagellates $\left(0.053 \pm 0.02 \mathrm{mg} . \mathrm{dm}^{-3}\right)$, whereas the highest biomass was found in Lake Dratów $\left(0.062 \pm 0.019 \mathrm{mg} . \mathrm{dm}^{-3}\right)$, but still no differences were found among the lakes $(F=0.55$, d.f. $=5, P=0.73)$. Ciliata displayed differences in biomass $(F=10.68$, d.f. $=5, \quad P=0.0004)$ that ranged between $30.67 \pm$ $8.50 \mu \mathrm{g} . \mathrm{dm}^{-3}$ in Lake Czarne Sosnowickie and $81.67 \pm$ $16.04 \mu \mathrm{g} . \mathrm{dm}^{-3}$ in Lake Dratów. The most abundant ciliates were Cinetochilum margaritaceum, Colpidium colpoda, Euplotes sp., Askenasia spp., Strombidium viride, Uronema spp. and Strombilidium spp.

\section{Components of the classical food web (chlorophyll-a, Cladocera, Copepoda, fish)}

The chlorophyll-a concentration ranged from $18.38 \pm 3.67 \mathrm{mg} . \mathrm{dm}^{-3}$ in Lake Czarne Sosnowickie to $149.74 \pm 88.12 \mathrm{mg} . d m^{-3}$ in Lake Krzczeń and differed 


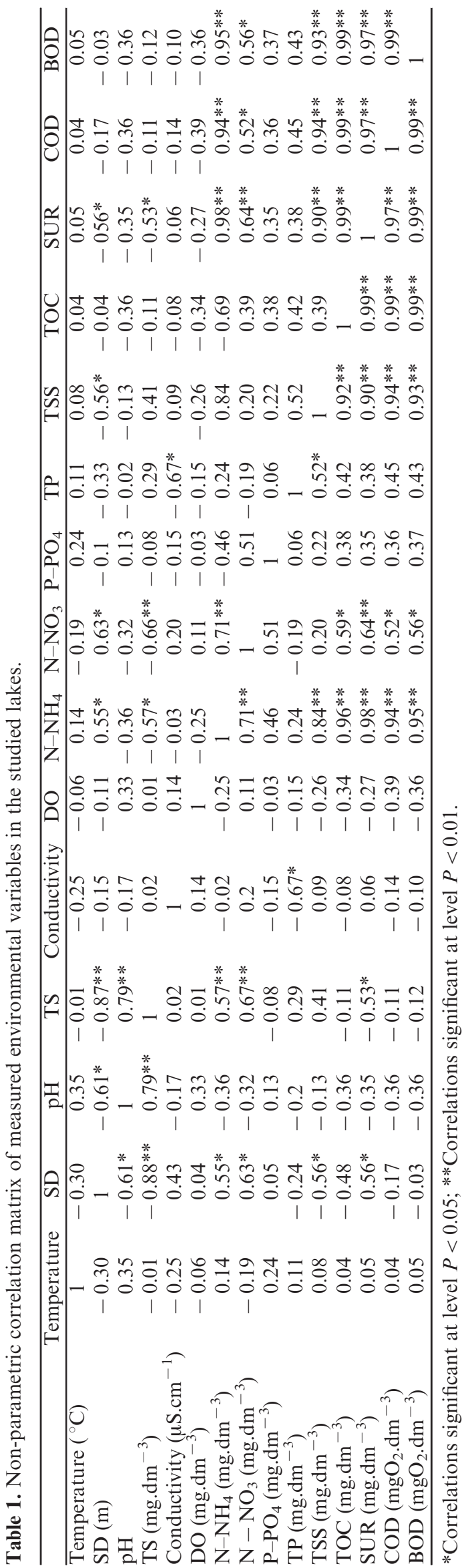

among lakes $(F=9.16$, d.f. $=5, P=0.0009)$. The biomass of Cladocera ranged from $1.02 \pm 0.98 \mathrm{mg} . \mathrm{dm}^{-3}$ in Lake Czarne Sosnowickie to $9.18 \pm 12.91 \mathrm{mg}^{-\mathrm{dm}^{-3}}$ in Lake Dratów and differed among lakes $(F=3.94$, d.f. $=5$, $P=0.028$ ). Daphnia longispina, Chydorus sphaericus and Bosmina longirostris were more abundant in the spring and autumn samples, whereas in the summer samples the species Diaphanosoma brachyurum, Daphnia cucullata, Bosmina coregoni and Ceriodaphnia quadrangula prevailed. The biomass of Copepoda ranged from $0.06 \pm$ $0.07 \mathrm{mg} . \mathrm{dm}^{-3}$ in Lake Krzczeń to $1.39 \pm 1.05 \mathrm{mg} . \mathrm{dm}^{-3}$ in Lake Dratów and showed differences among the studied lakes $(F=3.44$, d.f. $=5, P=0.029)$. Samples were apparently split into two groups, namely the spring and autumn samples had dominant larvae and immature individuals and the summer samples had dominant cyclopoids Mesocyclops leuckartii and Thermocyclops crassus as well as calanoid Eudiaptomus gracilodes.

The fish showed differences in biomass $(F=18.07$, d.f. $=5, P=0.0001)$ which was from $2361 \pm 964$ WPUE in Lake Krzczeń to $6991 \pm 2252$ WPUE in Lake Białe Sosnowickie. The dominant species were roach Rutilus rutilus, bream Abramis brama and ruffe Gymnocephalus cernuus. No piscivorous fish were caught in Lake Czarne Sosnowickie. In the remaining lakes, the biomass of piscivorous fish ranged from $366.5 \pm 324.1$ WPUE in Lake Domaszne to $1488 \pm 2288.1$ WPUE in Lake Białe Sosnowickie and differed among lakes $(F=18.07$, d.f. $=5$, $P=0.0001$ ). This group was represented by perch Perca fluviatilis and pike Esox lucius.

\section{Environmental background}

Most environmental factors showed differences among the studied lakes, including chl-a $(F=50.71$, d.f. $=5$, $P=0.00003)$, TOC, TSS, N-NH $4=5.23-55.0$, d.f. $=5$, $P<0.001)$, SD, TS and conductivity $(F=3.80-5.89$, d.f. $=5, P<0.05$ ). Some pairs of factors strongly correlated. Positive values of correlation coefficients were found among $\mathrm{N}-\mathrm{NO}_{3}, \mathrm{~N}-\mathrm{NH}_{4}, \mathrm{TS}$, TSS, TOC, SUR, COD and BOD. Negative correlations were obtained among SD, $\mathrm{pH}$, TSS and TS (Table 1$)$. The RDA axis $1(\lambda=0.587)$ and axis $2(\lambda=0.112)$ explained $87.5 \%$ of total variance of local factors in the communities' composition. However, variables that significantly explained variance in the communities included three factors: TS $(\lambda=0.39, P=0.002$, $F=10.13)$, temperature $(\lambda=0.23, P=0.002, F=9.48)$ and $\mathrm{SD}(\lambda=0.006, P=0.036, F=2.48)$ (Figure 2$)$. TV of TS at a level of $9.60 \mathrm{mg} . \mathrm{dm}^{-3}$ differed for the bacteria $(F=6.09$, $P=0.0049)$, ciliates $(F=4.65, P=0.022)$ and Cladocera $(F=3.94, P=0.028)$. The threshold temperature for the communities was $13.36^{\circ} \mathrm{C}$, and then it differed for the two communities, namely $\mathrm{HNF}(F=7.05, P=0.023)$ and copepods $(F=6.19, P=0.047)$. SD differed only for the Cladocera $(F=2.78, P=0.037)$, and the threshold level for that factor was $0.5 \mathrm{~m}$. Only these factors were taken under consideration for further analyses of correlations between components of the microbial and classical food web. 


\section{Correlations between components of the microbial and classical food web in different variants of environmental factors}

Under conditions of low TS, bacteria and HNF correlated positively to $\mathrm{N}-\mathrm{NH}_{4}$ and $\mathrm{N}-\mathrm{NO}_{3}$. Ciliates correlated negatively to the calanoid Eudiaptomus graciloides. Chlorophyll-a values correlated positively to $\mathrm{P}_{-} \mathrm{PO}_{4}$ and negatively to Calanoidae copepodites and the cladoceran B. longirostris. Under high TS, bacteria correlated to the cladoceran $B$. longirostris. Positive correlations between bacteria and nauplii, Cyclopoidae copepodites as well the calanoid E. graciloides were also found. Negative correlations were noted between HNF and cladocerans, including B. longirostris and D. cucullata. Adult cyclopoids correlated positively to planktivorous fish (Table 2).

In low temperature, bacteria correlated positively to the cladoceran $B$. longirostris. Positive correlations were found between HNF and planktivorous fish. Under high temperature, positive correlations between bacteria and nauplii were found. HNF correlated negatively to copepodites, and ciliates correlated negatively to copepodites and adult cyclopoids, including $T$. crassus and $M$. leuckartii. The cladoceran $D$. cucullata and adult cyclopoids correlated negatively to planktivorous fish (Table 2).

Under low SD, bacteria correlated positively to Cyclopoidae copepodites and the calanoid E. graciloides. Negative correlations were noted between HNF and cladocerans, including B. longirostris and D. cucullata. Ciliates correlated negatively to copepodites. Under conditions of high SD, positive correlations were found between bacteria and nauplii, Cyclopoidae copepodites as well as the calanoid E. graciloides, and negative correlations were noted between flagellates and the cladocerans B. longirostris and D. cucullata (Table 2).

\section{Discussion}

\section{Correlations between components of the microbial and classical food web}

HNF are thought to be the main consumers of bacteria in freshwater (Riemann, 1985; Güde, 1986); ciliates consume both bacteria (Simek et al., 1995) and HNF, thus the abundance of HNF often decreases as it is associated with the development of ciliates (Zöllner et al., 2003). However, in the present study insignificant correlations were found among these three components. Correlation analyses showed that in the studied lakes, links between microbial and classical food webs occurred at each level of the microbial loop. Evidence for the cascading effect of crustaceans on bacteria mainly came from meso- and microcosm experiments, but the effect of crustaceans on bacteria in natural conditions was also proved (Moustaka-Gouni and Vardaka, 2006). It is generally considered that crustacean plankton affect the whole microbial food web, i.e., from ciliates to larger bacteria (Jürgens and Stolpe, 1995). Filter-feeding cladocerans can directly capture bacteria,

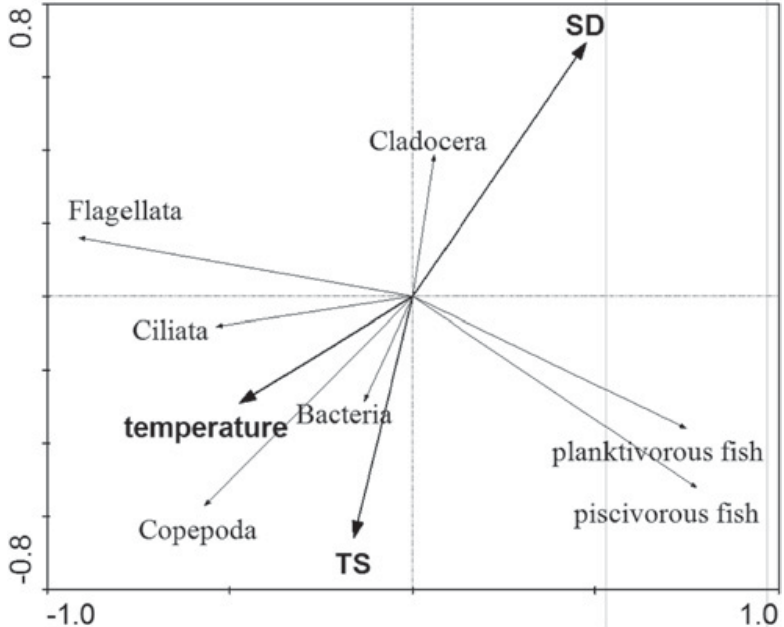

Fig. 2. Redundancy analysis (RDA) biplot showing the studied communities and environmental factors.

but can also indirectly control bacterial communities through trophic cascades (Langenheder and Jürgens, 2001), whereas copepods can selectively graze on ciliates and thereby indirectly control the bacteria (Burns and Schallenberg, 2001). In the present study, bacteria correlated positively to zooplankton, which is in accordance with many studies showing that it is impossible to show that predators diminish bacteria abundance, for bacteria are soon compensated by high production rates, thus the predators leave no visible effect (Adrian et al., 2001; Zöllner et al., 2003). But an inverse scenario of bacteria positively influencing higher trophic levels is highly possible. In most reports bacteria appear to be limited primarily by resources, whereas the top-down effect was never strong enough to produce negative bacterial growth rates (Billen et al., 1990; Pace and Cole, 1994; Jürgens and Jeppesen, 2000). Positive correlations were found between bacteria and larvae (nauplii) as well as juvenile (copepodite) stages of Copepoda. Copepod nauplii can ingest pico- and nanophytoplankton (Uye and Kasahara, 1983), and bacterioplankton can also constitute an important food source (Turner and Tester, 1992; Roff et al., 1995). Abundant and 'never-ending' sources of bacteria as food could affect the development of nauplii, of which the highest number endured to copepodite stages. Nauplii have higher rates of clearance of bacteria in the absence of alternative phytoplankton food (Turner and Tester, 1992). In the studied lakes, significant correlations between chlorophyll-a and higher trophic levels were found quite rarely, thus suggesting that phytoplankton could have a less important role in energy transfer along food webs, and phytoplankton particles were supposedly inedible by herbivorous and omnivorous species. As was mentioned above, there was a connection between bacteria and nauplii, but a high correlation between bacteria and cladoceran $B$. longirostris was also observed. HNF were preyed upon by cladocerans and copepods (in both juvenile and adult stages). The abilities of Daphnia and Bosmina to depress ciliata growth are well documented (Jürgens, 1994; 
Table 2. Pearson's correlations between trophic levels of microbial and classical food webs under low and high values of local stressors.

\begin{tabular}{|c|c|c|c|c|c|c|}
\hline & \multicolumn{2}{|c|}{$\mathrm{TS}$} & \multicolumn{2}{|c|}{ Temperature } & \multicolumn{2}{|c|}{ SD } \\
\hline & $\mathrm{L}$ & $\mathrm{H}$ & $\mathrm{L}$ & $\mathrm{H}$ & $\mathrm{L}$ & $\mathrm{H}$ \\
\hline Bacteria $-\mathrm{N}-\mathrm{NH}_{4}$ & $\begin{array}{l}r=0.49 \\
P=0.026\end{array}$ & - & - & - & - & - \\
\hline Bacteria $-\mathrm{N}-\mathrm{NO}_{3}$ & $\begin{array}{l}r=0.71 \\
P=0.049\end{array}$ & - & - & - & - & 一 \\
\hline Bacteria $-B$. longirostris & - & $\begin{array}{l}r=0.71 \\
P=0.003\end{array}$ & $\begin{array}{l}r=0.39 \\
P=0.048\end{array}$ & - & - & - \\
\hline Bacteria - nauplii & - & $\begin{array}{l}r=0.48 \\
P=0.017\end{array}$ & - & $\begin{array}{l}r=0.57 \\
P=0.049\end{array}$ & 一 & $\begin{array}{l}r=0.46 \\
P=0.028\end{array}$ \\
\hline $\begin{array}{l}\text { Bacteria - Cyclopoidae } \\
\text { copepodites }\end{array}$ & - & $\begin{array}{l}r=0.72 \\
P=0.025\end{array}$ & - & - & $\begin{array}{l}r=0.91 \\
P=0.000019\end{array}$ & $\begin{array}{l}r=0.67 \\
P=0.013\end{array}$ \\
\hline Bacteria - E. graciloides & - & $\begin{array}{l}r=0.45 \\
P=0.015\end{array}$ & - & $\begin{array}{l}r=0.41 \\
P=0.037\end{array}$ & $\begin{array}{l}r=0.41 \\
P=0.001\end{array}$ & \\
\hline Flagellates $-\mathrm{N}-\mathrm{NH}_{4}$ & $\begin{array}{l}r=0.049 \\
P=0.015\end{array}$ & - & - & - & - & - \\
\hline Flagellates $-\mathrm{N}-\mathrm{NO}_{3}$ & $\begin{array}{l}r=0.42 \\
P=0.025\end{array}$ & - & - & - & - & - \\
\hline Flagellates $-B$. longirostris & - & $\begin{array}{l}r=-0.31 \\
P=0.041\end{array}$ & - & - & $\begin{array}{l}r=-0.76 \\
P=0.023\end{array}$ & $\begin{array}{l}r=-0.53 \\
P=0.036\end{array}$ \\
\hline Flagellates $-D$. cucullata & - & - & - & - & $\begin{array}{l}r=-0.44 \\
P=0.029\end{array}$ & - \\
\hline Flagellates - copepodites & - & - & - & $\begin{array}{l}r=-0.78 \\
P=0.031\end{array}$ & - & - \\
\hline Flagellates - planktivorous fish & 一 & - & $\begin{array}{l}r=0.39 \\
P=0.046\end{array}$ & - & - & - \\
\hline Ciliates - copepodites & - & - & - & - & $\begin{array}{l}r=-0.39 \\
P=0.027\end{array}$ & $\begin{array}{l}r=-0.46 \\
P=0.018\end{array}$ \\
\hline Ciliates - adult cyclopoids & $\begin{array}{l}r=-0.78 \\
P=0.046\end{array}$ & $\begin{array}{l}r=-0.61 \\
P=0.040\end{array}$ & - & $\begin{array}{l}r=-0.76 \\
P=0.021\end{array}$ & - & - \\
\hline Ciliates $-T$. crassus & - & - & $\begin{array}{l}r=-0.72 \\
P=0.014\end{array}$ & - & - & - \\
\hline Ciliates $-M$. leuckartii & 一 & - & - & $\begin{array}{l}r=-0.55 \\
P=0.017\end{array}$ & - & - \\
\hline Ciliates $-E$. graciloides & $\begin{array}{l}r=-0.37 \\
P=0.048\end{array}$ & $\begin{array}{l}r=-0.39 \\
P=0.017\end{array}$ & - & - & - & - \\
\hline Chlorophyll-a - P- $\mathrm{PO}_{4}$ & $\begin{array}{l}r=0.63 \\
P=0.022\end{array}$ & - & - & - & - & - \\
\hline $\begin{array}{l}\text { Chlorophyll-a - Calanoidae } \\
\text { copepodites }\end{array}$ & $\begin{array}{l}r=-0.39 \\
P=0.031\end{array}$ & - & $\begin{array}{l}r=-0.59 \\
P=0.018\end{array}$ & - & - & - \\
\hline Chlorophyll-a - B. longirostris & $\begin{array}{l}r=-0.49 \\
P=0.031\end{array}$ & - & - & - & - & - \\
\hline D. cucullata-planktivorous fish & - & - & - & $\begin{array}{l}r=-0.82 \\
P=0.038\end{array}$ & - & - \\
\hline $\begin{array}{l}\text { Adult cyclopoids - planktivorous } \\
\text { Fish }\end{array}$ & - & $\begin{array}{l}r=0.49 \\
P=0.017\end{array}$ & - & $\begin{array}{l}r=0.37 \\
P=0.031\end{array}$ & - & - \\
\hline
\end{tabular}

$\mathrm{L}$ and $\mathrm{H}$ abbreviations mean, respectively, low and high values of environmental variables estimated empirically, '-' means insignificant correlations $(P>0.05)$.

Burns and Schallenberg, 1996), but in the studied lakes these taxa did not significantly affect ciliates that were mainly consumed by copepods. Among the crustaceans, negative correlations were found between D. cucullata and planktivorous fish, whereas Cyclopoidae copepods correlated to planktivorous fish, however, these relations occurred only under conditions of high TS and temperature. Although research by Müller-Solger et al. (1997) showed that the presence of planktivorous fish can influence significant increases in the density of ciliates, no positive fish-ciliate relations were found in the studied lakes.

\section{Contribution of environmental factors to food web relations}

Variation partitioning based on RDA revealed that local factors played the most important roles in structuring the aquatic communities by explaining $87.5 \%$ in their variation. Among all of the factors measured, total solids (TS), transparency (SD) and temperature were most closely related to variation in trophic communities.

The TS concentration contributed the most to this variation. Under that factor the largest number of 
interactions was found between trophic levels. In comparison to other factors, this one influenced the strongest bacteria communities. Under high TS, significant relationships between bacteria and cladocerans and all developmental stages of Copepoda were found. Probably detrital particles constituting mostly TS created a medium for bacterial development. Some studies have reported that more than half of the bacterioplankton in aquatic ecosystems can be attached to detrital particles (Simon, 1987; Riemann et al., 2000), and the abundance of those particles influences the density, biomass and production of the attached bacteria (Kepkay, 1994; Carrias et al., 2002). Both cladocerans and copepods can consume particles, including the attached bacteria (Shimeta, 1993; Lemarchand et al., 2006), and detrital particles with attached bacteria can often be more quantitatively important food for zooplankton than algae (Gons et al., 1992). Thus, such particles could be an important non-algal food source for crustaceans; all the more that according to Marzolf (1990), phytoplankton alone do not satisfy all of the nutritional requirements of zooplankton. Only under low TS conditions are bacteria correlated to biogenes, therefore a high TS concentration seemed to autonomize the bacteria to biogenes.

Virtually all aspects of physiology, including grazing (Kiørboe et al., 1982; Houde and Roman, 1987), respiration (Ikeda, 1985; Thor et al., 2002), timing of reproduction and onthogenetic development (Dell et al., 2011), are impacted by temperature. As temperature directly interacts in reducing or enhancing the metabolism and reproduce rates (Green, 1966; Frey, 1982; Gillooly and Dodson, 2000; de Eyto and Irvine, 2001), it has multiple indirect effects on aquatic communities' habitats by altering food resources. There have been observations that temperature can significantly influence variation in communities of microbial (Shiah and Ducklow, 1994; Lepère et al., 2006; Mieczan et al., 2013) and classical (Alofs et al., 2014; Xin et al., 2014) food webs. The effect of temperature on food web relations has been widely studied due to observed increases in global temperature (Petchey et al., 1999; O'Connor et al. 2009; Beveridge et al. 2010). The present study showed that temperature influenced the food web in two ways. Low temperature weakened strengths among distinct trophic levels and impaired relations between microbial and classical food webs. High temperature, in turn, enhanced negative correlations between consecutive trophic levels, from planktivorous fish to HNF. The effect of temperature on food web interactions probably resulted from the role that factor plays in physiological processes, including the ingestion rate (Delaney, 2003). Thus, high temperature triggered the grazing mechanisms through distinct levels of the food web suggesting top-down control.

Another factor that significantly influenced aquatic communities was SD. Foraging of most planktivorous fish is directed by vision (Lazzaro, 1987), thus that factor can determine the abundance of some aquatic communities, especially crustaceans (Estlander et al., 2009). Planktonic crustaceans can be protected against predation by water turbidity, for suspended particles severely disturb prey detection by fish due to their effects on light scattering (Horppila et al., 2004). Because water transparency is important in order for crustaceans to avoid predators, it has less importance for their foraging since cladocerans forage unselectively (Burns, 1968), and copepods use mechanoreceptors to detect their prey (Williamson, 1986) and chemoreceptors to capture the most nutritional particles (Paffenhöfer and Van Sant, 1985). Insignificant differences in food web interactions were found between low and high transparency conditions. Although high transparency should favour planktivorous fish to seek prey, suggesting inverse correlations between fish and crustaceans, no significant interactions were found between these two communities. At lower trophic levels, both under low and high SD, crustaceans negatively influenced ciliates and HNF, while positive correlations between bacteria and crustaceans were found. The lack of expected evidence between planktivorous fish and crustaceans probably resulted from the ability of the latter community to conduct horizontal and vertical migrations to avoid predation pressure (Wissel et al., 2003; Adamczuk, 2012; Adamczuk and Mieczan, 2013). Therefore, in conditions of high transparency, the active choice of crustacean plankton to avoid predatory pressure could hamper topdown control and influence interactions at lower trophic levels, thus converge them to those in conditions of low water transparency.

\section{Conclusions}

In most studies, environmental factors are considered as factors influencing the abundances of aquatic communities, whereas their regulating role in food web interactions is often underestimated. The study revealed that environmental factors influence food web interactions and play an important regulating role in bottom-up or topdown control. Taking into consideration the fact that environmental factors change not only on the perennial or seasonal scale but also in diel duration, they may trigger a variety of interaction patterns even in a short period of time. It is considered that cladocerans, especially Daphnia, affect whole microbial food web, but the study proved that copepods could have a key role in transferring energy from microbial to classical food web, because their grazing effect was quite resistant to local stressor and occurred at each developmental stage, including larvae, immature and mature individuals.

Acknowledgements. We would like to thank the two anonymous reviewers. Their constructive criticism helped greatly improve the previous draft of the paper.

\section{References}

Adamczuk M., 2012. Spatial distribution of juvenile and adult stages of limnetic Cladocera in relation to selected environmental factors. J. Limnol., 71, 112-118. 
Adamczuk M. and Mieczan T., 2013. Spatial distribution of brood-bearing females of limnetic species of Cladocera. C. R. Biol., 336, 457-465.

Adrian R., Wickham S.A. and Butler N.M., 2001. Trophic interactions between zooplankton and the microbial community in the contrasting food webs: the epilimnion and deep chlorophyll maximum of a mesotrophic lake. Aquat. Microb. Ecol., 24, 83-97.

Alofs K.M., Jackson D.A. and Lester N.P., 2014. Ontario freshwater fishes demonstrate differing range-boundary shifts in a warming climate. Divers. Distrib., 20, 123-136.

Appelberg M., 2000. Swedish standard methods for sampling freshwater fish with multi-mesh gillnets. Fiskeriverket Inf., 2000,1 .

Augustin H., Foissner W. and Adam H., 1984. An improved pyridinated silver carbonate method which need few specimens and yields permanent slides of impregnation ciliates (Protozoa, Ciliophora). Mikroskopie, 41, 134-137.

Beaver J.R. and Crisman T.L., 1982. The trophic response of ciliated protozoans in fresh-water lakes. Limnol. Oceanogr., 27, 246-253.

Beveridge O.S., Humpries S. and Petchey O.L., 2010. The interacting effects of temperature and food chain length on trophic abundance and ecosystem function. J. Anim. Ecol., 79, 693-700.

Billen G., Servais P. and Becquevort S., 1990. Dynamics of bacterioplankton in oligotrophic and eutrophic aquatic environments: bottom up or top-down control? Hydrobiologia, 207, 37-42.

Bottrell H.H., Duncan A., Gliwicz Z.M., Grygierek E., Herzig A., Hillbricht - Ilkowska A., Kurasawa H., Larsson P. and Węgleńska T., 1976. Review of some problems in zooplankton production studies. Norw. J. Zool., 24, 419-456.

Brett M.T. and Goldman C.R., 1996. A meta-analysis of the freshwater trophic cascade. Proc. Natl. Acad.Sci. U.S.A., 93, 7723-7726.

Brett M.T. and Goldman C.R., 1997. Consumer versus resource control in freshwater pelagic food webs. Science, 275, 384-386.

Burns C.W., 1968. The relationship between body size of filterfeeding Cladocera and the maximum size of particle ingested. Limnol. Oceanogr., 13, 675-678.

Burns C.W. and Schallenberg M., 1996. Relative impacts of copepods, cladocerans and nutrients on the microbial food web of a mesotrophic lake. J. Plankton Res., 18, 683-714.

Burns C.W. and Schallenberg M., 2001. Calanoid copepods versus cladocerans: consumer effects on protozoa in lakes of different trophic status. Limnol. Oceanogr., 46, 1558-1565.

Carpenter S.R., Kitchell J.F. and Hodgson J.R., 1985. Cascading trophic interactions and lake productivity. Bioscience, 35, 634-639.

Carrias J.F., Serre J.P., Sime-Ngando T. and Amblard C., 2002. Distribution, size, and bacterial colonization of pico- and nano-detrital organic particles (DOP) in two lakes of different trophic status. Limnol. Oceanogr., 47, 1202-1209.

CEN document, 2005. Water quality - Sampling of fish with multi-mesh gillnets. EN 14757: 2005.

Culver D.A., Boucherle M.M., Bean D.J. and Fletcher W.J., 1985. Biomass of freshwater crustacean zooplankton from lenght-weight regression. Can. J. Fish. Aquat. Sci., 42, $1380-1390$.
Dawidek J., Sobolewski S. and Turczyński M., 2004. Transformations of catchmet-areas of lakes converted into storage reservoirs in the Wieprz-Krzna Canal system. Limnol. Rev., 4, 67-74.

Dawidek J., Ferencz B. and Sobolewski W., 2013. Modelling of hydrogeochemical potential of three lake catchments in Polesie region (Eastern Poland). Hydrol. Process., 27, 1773-1780.

de Eyto E. and Irvine K., 2001. The response of three chydorid species to temperature, $\mathrm{pH}$ and food. Hydrobiologia, 459, 165-172.

Delaney M.P., 2003. Effects of temperature and turbulence on predator-prey interactions between a bacterotrophic flagellate and a marine bacterium. Microb. Ecol., 45, 218-225.

Dell A.J., Pawar S. and Savage V.M., 2011. Systematic variation in the temperature dependence of physiological and ecological traits. Proc. Natl. Acad. Sci. U.S.A., 108, 10591-10596.

Dumont H.J., Van de Velde I. and Dumont S., 1975. The dry weight estimate of biomass in selection of Cladocera, Copepoda and Rotifera from the plankton, periphiton and benthos of continental waters. Oecologia, 19, 75-97.

Estlander S., Nurminen L., Olin M., Vinni M. and Horppila J., 2009. Seasonal fluctuations in macrophyte cover and water transparency of four brown-water lakes: implications for crustacean zooplankton in littoral and pelagic habitats. Hydrobiologia, 620, 109-120.

Finlay B.J., 1982. Procedures for the isolation, cultivation and identification of protozoa. Exp. Microb. Ecol., 1, 44-65.

Frey D.G., 1982. Contrasting strategies of gametogenesis in northern and southern populations of Cladocera. Ecology, 63, 223-241.

Gilbert D., Amblard C., Bourdier G. and Francez A.J., 1998. The microbial loop at the surface of a peatland: structure, functioning and impact of nutrients inputs. Microb. Ecol., 35, 89-93.

Gillooly J.F. and Dodson S.I., 2000. Latitudinal patterns in the size distribution and seasonal dynamics of new world, freshwater cladocerans. Limnol. Oceanogr., 45, 22-30.

Golterman H.L., 1969. Methods for Chemical Analysis of Freshwaters, Blackwell Scientific Publications, Oxford, Edinburgh, 172 p.

Gons H.J., Berger-Wiersma T., Otten J.H. and Rijkeboer M., 1992. Coupling of phytoplanbkton and detritus in a shallow, eutrophic lake (Lake Loosdrecht, The Netherlands). Hydrobiologia, 233, 51-59.

Green J., 1966. Seasonal variation in egg producton by Cladocera. J. Anim. Ecol., 35, 77-104.

Güde H., 1986. Loss processes influencing growth of planktonic bacterial populations in Lake Constance. J. Plankton Res., 8, 795-810.

Horppila J., Liljendahl-Nurminen A. and Malinen T., 2004. Effect of clay turbidity and light on the predator-prey interactions between smelts and chaoborids. Can. J. Fish. Aquat. Sci., 61, 1862-1870.

Houde S.E.L. and Roman M.R., 1987. Effects of food quality on the functional ingestion response of the copepod Acartia tonsa. Mar. Ecol. Prog. Ser., 40, 69-77.

Ikeda T., 1985. Metabolic rates of epipelagic marine copepods as a function of body mass and temperature. Mar. Biol., 85, $1-11$. 
Jack J.D. and Gilbert J.J., 1993. Susceptibilities of different-sized ciliates to direct suppression by small and large cladocerans. Freshwat. Biol., 29, 19-29.

Jerome C.A., Montagnes D.J.S. and Taylor F.J.R., 1993. The effect of the quantitative protargol stain and Lugols and Buinos fixatives on cell size: A more accurate estimate ciliate species biomass. J. Eukaryot. Microbiol., 40, 254-259.

Jürgens K., 1994. Impact of Daphnia on planktonic microbial food webs - a review. Mar. Microb. Food Webs, 8, 295-324.

Jürgens K. and Jeppesen E., 2000. The impact of metazooplankton on the structure of the microbial food web in a shallow, hypereutrophic lake. J. Plankton Res., 22, 1047-1070.

Jürgens K. and Stolpe G., 1995. Seasonal dynamics of crustacean zooplankton, heterotrophic nanoflagellates and bacteria in a shallow, eutrophic lake. Freshwat. Biol., 33, 27-38.

Kalinowska K., 2004. Bacteria, nanoflagellates and ciliates as components of the microbial loop in three lakes of different trophic status. Pol. J. Ecol., 52, 19-34.

Kepkay P.E., 1994. Particle aggregation and the biological reactivity of colloids. Mar. Ecol. Prog. Ser., 109, 293-304.

Kiørboe T., Møhlenberg F. and Hamburger K., 1982. Ingestion rate and gut clearance on the planktonic copepod Centropages hamatus (Lilljeborg) in relation to food concentration and temperature. Ophelia, 21, 181-194.

Langenheder S. and Jürgens K., 2001. Regulation of bacterial biomass and community structure by metazoan and protozoan predation. Limnol. Oceanogr., 46, 121-134.

Lazzaro X., 1987. A review of planktivorous fishes: their evolution, feeding bahaviours, selectivities and impacts. Hydrobiologia, 146, 97-167.

Lemarchand C., Jardillier L., Carrias J.F., Richardot M., Debroas D., Sime-Ngando T. and Amblard C., 2006. Community composition and activity of prokaryotes associated to detrital particles in two contrasting lake ecosystems. FEMS Microbiol. Ecol., 57, 442-451.

Lepère C., Boucher D., Jardillier L., Domaizon I. and Debroas D., 2006. Succession and regulation factors of small eukaryote community composition in a lacustrine ecosystem (Lake Pavin). Appl. Environ. Microbiol., 72, 2971-2981.

Lepš J. and Šmilauer P., 2003. Multivariate Analysis of Ecological Data using CANOCO, University Press, Cambridge, $251 \mathrm{p}$.

Marzolf G.R., 1990. Reservoirs as environments for zooplankton. In: Thornton K.W., Kimmel B.L. and Payne F.E. (eds.), Reservoir Limnology: Ecological Perspectives, John Wiley and Sons, New York, 195-208.

Mieczan T., Adamczuk M. and Nawrot D., 2013. Effect of water chemistry on the planktonic communities and relationships among food web components across a freshwater ecotone. Arch. Biol. Sci., 64, 1491-1504.

Moustaka-Gouni M. and Vardaka E., 2006. Plankton food web structure in a eutrophic polymictic lake with a history of toxic cyanobacterial blooms. Limnol. Oceanogr., 51, $715-727$.

Müller-Solger A., Brett M.T., Luecke C., Elser J.J. and Goldman C.R., 1997. The effect of planktivorous fish (golden shiners) on the ciliate community of a mesotrophic lake. J. Plankton Res., 19, 1815-1828.
O’Connor M.J., Piehler M.F., Leech D.M., Anton A. and Bruno J.F., 2009. Warming and resource availability shift food web structure and metabolism. PloS Biol., 7, e1000178.

Pace M.L. and Cole J.J., 1994. Comparative and experimental approaches to top-down and bottom-up regulation of bacteria. Microb. Ecol., 28, 181-183.

Paffenhöffer G.A. and Van Sant K.B., 1985. The feeding response of marine planktonic copepods to quantity and quality of particles. Mar. Ecol. Prog. Ser., 27, 55-65.

Petchey O.L., McPhearson P.T., Casey T.M. and Morin P.J., 1999. Environmental warming alters food-web structure and ecosystem function. Nature, 402, 69-72.

Pimm S.L., Lawton J.H. and Cohen J.E., 1991. Food web patterns and their consequences. Nature, 350, 669-674.

Porter K.G. and Feig Y.S., 1980. The use of DAPI for identifying and counting aquatic microflora. Limnol. Oceanogr., 25, 943-948.

Riemann B., 1985. Potential importance of fish predation and zooplankton grazing on natural populations of freshwater bacteria. Appl. Environ. Microb., 50, 187-193.

Riemann L., Steward G.F. and Azam F., 2000. Dynamics of bacterial community composition and activity in a mesocosm diatom bloom. Appl. Environ. Microb., 66, 578-587.

Roff J.C., Turner J.T., Webber M.K. and Hopcroft R.R., 1995. Bacterivory by tropical copepod nauplii: extent and possible significance. Aquat. Microb. Ecol., 9, 165-175.

Shiah F.K. and Ducklow H., 1994. Temperature regulation of heterotrophic bacterioplankton abundance, production, and specific growth rate in Chesapeake Bay. Limnol. Oceanogr., 39, 1243-1250.

Shimeta J., 1993. Diffusional encounter of submicrometer particles and small cells by suspension feeders. Limnol. Oceanogr., 38, 456-465.

Simek K., Bobkova J., Macek M., Nemoda J. and Psener R., 1995. Ciliates grazing on picoplankton in a eutrophic reservoir during summer phytoplankton maximum - a study at the species and community level. Limnol. Oceanogr., 40, 1077-1090.

Simon M., 1987. Biomass and production of small and large freeliving and attached bacteria in Lake Constance. Limnol. Oceanogr., 32, 591-607.

Smil V., 2000. Phosphorus in the environment: natural flows and human interferences. Annu. Rev. Energy Env., 25, 53-88.

Straile D., Johnk K.D. and Rossknecht H., 2003. Complex effects of winter warming on the physicochemical characteristics of a deep lake. Limnol. Oceanogr., 48, 1432-1438.

Ter Braak C.J.F. and Šmilauer P., 2002. CANOCO reference manual and CanoDraw forWindows user's guide: software for canonical community ordination (version 4.5), Microcomputer Power, Ithaca, NY, 500 p.

Thor P., Cervetto G., Besihtepe S., Ribera-Maycas E., Tang K.W. and Dam H.G., 2002. Influence of two different green algal diets on specific dynamic action and incorporation of carbon into biochemical fractions in the copepod Acartia tonsa. J. Plankton Res., 24, 293-300.

Turner J.T. and Tester P.A., 1992. Zooplankton feeding ecology: bacterivory by metazoan microzooplankton. J. Exp. Mar. Biol. Ecol., 160, 149-167.

Uye S.I. and Kasahara S., 1983. Grazing of various developmental stages of Pseudodiaptomus marinus (Copepoda: Calanoida) on naturally occurring particles. Bull. Plankton Soc. Jpn., 30, 147-158. 
Wickham S.A., 1995a. Trophic relations between cyclopoid copepods and ciliated protists, complex interactions link the microbial and classic food webs. Limnol. Oceanogr., 40, 1173-1181.

Wickham S.A., 1995b. Cyclops predation on ciliates: speciesspecific differences and functional responses. J. Plankton Res., 17, 1633-1646.

Williamson C.E., 1986. The swimming and feeding behaviour of Mesocyclops. Hydrobiologia, 134, 11-19.

Winder M. and Schindler D.E., 2004. Climate change uncouples trophic interactions in and aquatic system. Ecology, 85, 2100-2106.
Wissel B., Boeing W.J. and Ramcharan C.W., 2003. Effects of water color on predation regimes and zooplankton assemblages in freshwater lakes. Limnol. Oceanogr., 48, 1965-1976.

Xin L., Beyrend-Dur D., Dur G. and Ban S., 2014. Effects of temperature on life-history traits of Eudiaptomus japonicus (Copepoda: Calanoida) from Lake Biwa (Japan). Limnology, $15,85-97$.

Zöllner E.H., Santer B., Boersma M., Hoppe H.G. and Jürgens K., 2003. Cascading predation effects of Daphnia and copepods on microbial food web components. Freshwat. Biol., 48, 2174-2193. 